\title{
A CHRONOLOGY OF THE PRE-COLUMBIAN PARACAS AND NASCA CULTURES IN SOUTH PERU BASED ON AMS ${ }^{14} \mathrm{C}$ DATING
}

\author{
Ingmar Unkel ${ }^{1,2} \bullet$ Bernd Kromer $^{1} \bullet$ Markus Reindel $^{3} \bullet$ Lukas Wacker $^{4} \bullet$ Günther Wagner $^{1}$
}

\begin{abstract}
The people of the Paracas and Nasca cultures, the creators of the famous geoglyphs, lived in the desert of the southern coast of Peru between about $800 \mathrm{BC}$ and $\mathrm{AD}$ 650. The archaeological chronology of these cultures has been based almost exclusively on a sequence of ceramic styles. The absolute dating of some of the style phases was supported by a few radiocarbon dates (Rowe 1967). Here, we present an absolute chronology of the Paracas and Nasca cultures based on ${ }^{14} \mathrm{C}$ dating of more than 100 organic samples from settlement and tomb relics, as well as on material derived from geoglyph sites in the Nasca/Palpa region (south Peru). The main focus has been on Nasca period settlement centers near Palpa, Los Molinos and La Muña, the Paracas period site of Jauranga, and the Initial period site of Pernil Alto. Most of the ${ }^{14} \mathrm{C}$ samples were dated at the accelerator mass spectrometry (AMS) facility of the ETH Zurich (Switzerland). The targets were produced in the newly built graphitization line at the Heidelberg ${ }^{14} \mathrm{C}$ laboratory (Germany). Clay (adobe) bricks, which are quite a common building material in Peru, were successfully tested to be used for AMS ${ }^{14} \mathrm{C}$ dating of adobe architecture in Peruvian archaeology.
\end{abstract}

\section{INTRODUCTION}

Ceramic is quite a durable cultural product and in most prehistoric cultures it has a marked chronological sensitivity. Therefore, ceramics are widely used among archaeologists to arrange ancient cultures spatially and temporally (Eggert 2001). Since the dawn of archaeological ceramic analyses, they have been used not only as a source of cultural information, but also as a tool to create a relative chronology of archaeological complexes, especially at the beginning of the 20th century when radiometric dating methods were still lacking. Thus, the arrangement of the chronological phases of the Paracas and Nasca cultures, which began to be studied in these times, was until now based on the seriation of ceramic styles.

In Peruvian archaeology, the ceramic classification based on single attributes, as introduced by James A Ford (Rowe 1959; Menzel 1971), was adapted by Rowe (1959) for the seriation of ceramic material from the southern coast of Peru in order to create a master chronology for the pre-Hispanic cultures of Peru. Rowe created the so-called "similiary seriation." This method is based on a nontypological, non-quantitative ceramic analysis, and the assumption that changes within a culture, which will be also expressed in its ceramic style, develop step-by-step from simplicity to complexity (for more detailed information see Wetter [2005]). Menzel et al. (1964) published a ceramic chronology of the Paracas with 10 Ocucaje phases. The last phase of this Paracas chronology, Ocucaje 10, incorporates similar style elements as the first phase of the Nasca chronology, Nasca 1; thus, this transitional period is referred to as the Initial Nasca or Proto-Nasca (see Tables 1-3) (Reindel et al. 1999; Lambers 2004).

The Ocucaje sequence (Table 1) was established on the basis of a huge amount of material in museums and private collections lacking information on archaeological contexts. Very few scientific excavations of Paracas sites have been conducted on the southern coast of Peru, and several relative chronologies with different phase designations exist (Reindel and Isla Cuadrado 2001; Wetter 2005).

\footnotetext{
${ }^{1}$ Heidelberg Academy of Sciences, c/o Institut für Umweltphysik, INF 229, 69120 Heidelberg, Germany.

2Corresponding author. Email: ingmar.unkel@geol.lu.se.

${ }^{3}$ German Archaeological Institute, Commission for the Archaeology of Extra-European Cultures, Endenicher Strasse 41, 53115 Bonn, Germany.

${ }^{4}$ Institute of Particle Physics, HPK H25, ETH-Hoenggerberg, 8093 Zurich, Switzerland.
} 
Table 1 Schematic comparison of 3 relative chronologies of the Early Horizon for the southern coast of Peru (according to Wetter 2005).

\begin{tabular}{|c|c|c|c|}
\hline & Menzel et al. (1964) & DeLeonardis (1997) & Reindel et al. (1999) \\
\hline $\begin{array}{l}\text { Early Intermed. } \\
\text { period }\end{array}$ & Nasca 1 & & Initial Nasca \\
\hline \multirow{7}{*}{$\begin{array}{l}\text { Early } \\
\text { Horizon }\end{array}$} & \multirow{3}{*}{$\begin{array}{l}\text { Ocucaje } 10 \\
\text { Ocucaje } 9 \\
\text { Ocucaje } 8 \\
\text { Ocucaje } 7 \\
\text { Ocucaje } 6\end{array}$} & \multirow{4}{*}{$\begin{array}{l}\text { Late Callango } \\
\text { (Ocucaje 6-7) }\end{array}$} & \\
\hline & & & Late Paracas \\
\hline & & & \multirow[t]{2}{*}{ Middle Paracas } \\
\hline & Ocucaje 5 & & \\
\hline & Ocucaje 4 & \multirow{2}{*}{$\begin{array}{l}\text { Middle Callango } \\
\text { (Ocucaje 3-8) }\end{array}$} & Early Paracas \\
\hline & Ocucaje 3 & & Lairy 1 diracas \\
\hline & $\begin{array}{l}\text { Ocucaje } 2 \\
\text { Ocucaje } 1\end{array}$ & $\begin{array}{l}\text { Early Callango } \\
\text { (Ocucaje 1-4) }\end{array}$ & \\
\hline Initial period & & & \\
\hline
\end{tabular}

The ceramic chronology of the Nasca period faces the same problem as that of the Paracas phase because much of the pottery underpinning the classification is derived from looted sites and lacks a stratigraphic context. The first descriptions of Nasca ceramics and attempts at a relative chronology were published by Joyce (1912) and Uhle (1914).

During the last century, a number of archaeologists worked on a systematic chronology of the Nasca time based on ceramic analyses with respect to the decoration style, iconography, and vessel type. Silverman and Proulx (2002) give an overview on the different elaborations; the ones mainly used are shown in Table 2. At first, 2 major stylistic elements were distinguished, believed to show a cultural development (Uhle 1914; Tello 1917): the naturalistic "monumental" style and the more abstract "proliferous" style. A change in the attempts at a classification of the Nasca pottery was introduced with Rowe's (1959) similiary seriation. This method was applied to the Nasca pottery by Lawrence Dawson. He developed a style chronology of 8 (or 9) phases that are still in use today (Table 2). However, Dawson never published his investigations himself. A summary of the style sequence was published by Rowe (1960).

Table 2 Comparative summary of the Nasca ceramic styles and the correlation to the respective phases (according to Silverman and Proulx 2002).

\begin{tabular}{llll}
\hline \multirow{2}{*}{ Stylistic strains } & $\begin{array}{l}\text { Dawson } \\
\text { (in Rowe 1960) }\end{array}$ & $\begin{array}{l}\text { Gayton and Kroeber } \\
(1927)\end{array}$ & Phases \\
\hline Disjunctive & 9 & Y-2, Y-3 & Wari \\
\cline { 2 - 4 } & 8 & Y-1 & Wari (Loro) \\
\hline Proliferous & 7 & B & Late Nasca \\
\cline { 2 - 4 } & 6 & X & Middle Nasca \\
\hline Transitional & 5 & A & Early Nasca \\
\hline Monumental & 4 & & Initial Nasca \\
\cline { 2 - 4 } & 3 & & \\
\cline { 2 - 4 } & 2 & &
\end{tabular}


The relative ceramic chronologies of the Paracas and Nasca periods described above lack not only information on the archaeological context of the ceramic used to construct them, but they also imply a number of uncertainties. Silverman and Proulx (2002), for example, mention regional differences in ceramic style elements that may be misinterpreted as chronological stages. That this has to be considered carefully becomes clear when looking at the geomorphological complexity of the Rio Grande de Nasca Valley system (Figure 1). For instance, due to the strong morphological division in the area, styles could have been maintained at some places, while elsewhere new styles were already being developed. Furthermore, what is regarded as "chronological" can be an expression of the style of families or different social groups. Also, functional differences, e.g. between ceremonial and domestic use, can be falsely interpreted as chronological development (Wetter 2005).

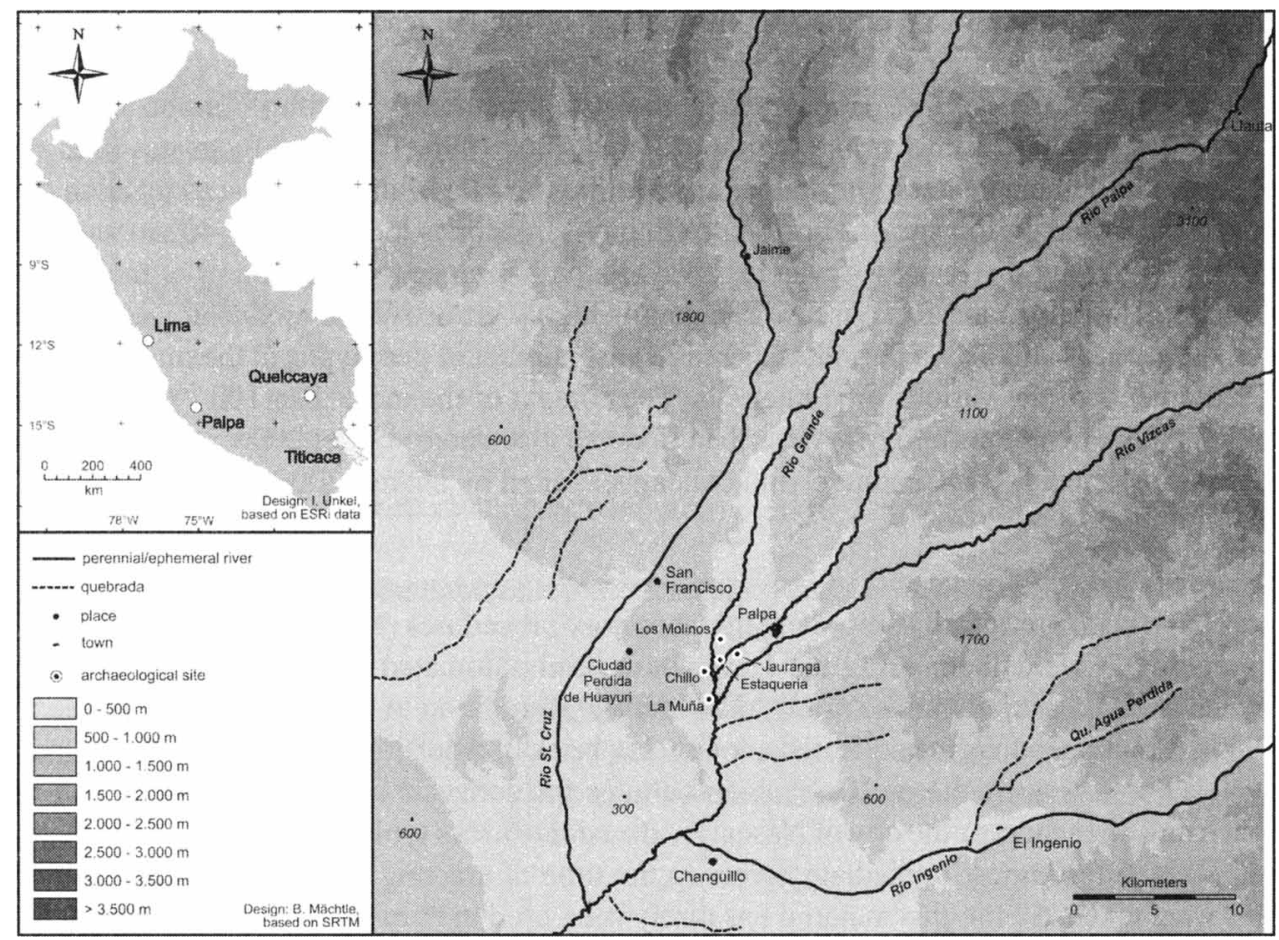

Figure 1 Map of the study area around Palpa

Recently, archaeologists of the German Archaeological Institute have been attempting to rework the existing Paracas (Wetter 2005) and Nasca (Hecht 2007) ceramic classification. The aim is to establish a classification that is based on a wide range of characteristics, such as the previously neglected ware type and pottery shape, and is derived from well-documented and well-stratified archaeological excavations. These new investigations are the relative-chronological framework for the numerical ${ }^{14} \mathrm{C}$ chronology of the Paracas and Nasca time presented below.

The existing attempts towards a numerical chronology of the Paracas culture are controversial (Velarde 1997). The onset of the so-called Early Horizon varies up to $900 \mathrm{yr}$ depending on the author (Paul 1991). This conflict is based on ${ }^{14} \mathrm{C}$ dates that are either derived from less meaningful archaeological complexes or belong to locations like Chavin de Huantar that are far away from the centers of the Paracas culture and are parallelized by stylistic comparison (Burger 1981). In attempting to 
fix the end of the Paracas period and the start of the Nasca period, meaning the onset of the Early Intermediate period, the archaeological opinions vary less, but still up to $200 \mathrm{yr}$ (Silverman 1991).

In the past, numeric or chronometric data of the Paracas and Nasca cultures were often derived from badly documented excavational contexts and were often ambiguous, making it difficult to classify archaeological remains from recent excavations in the Palpa region (Figure 1) (Reindel et al. 2003). Silverman and Proulx (2002) also emphasize the dire need for a well-documented, consistent, and calibrated ${ }^{14} \mathrm{C}$ chronology of that period, as they lack these requirements in the ${ }^{14} \mathrm{C}$ data published on Nasca issues so far (Rowe 1967; Disselhoff 1969; Ziolkowski et al. 1994).

\section{ARCHAEOLOGICAL CONTEXT}

The archaeological framework of the ${ }^{14} \mathrm{C}$ chronology of the Paracas and Nasca periods presented here is based upon excavations conducted under the guidance of Markus Reindel (German Archaeological Institute, DAI-KAAK, Bonn) and Johny Isla Cuadrado (Instituto Andino de Estudios Arqueológicos, INDEA, Lima) in the region of Palpa since 1996. The main focus has been on the Nasca period settlement centers near Palpa, Los Molinos and La Muña, the Paracas location of Jauranga, and the Initial period site of Pernil Alto (Figure 1). Palpa is located about $40 \mathrm{~km}$ north of the town of Nazca, along the Panamericana highway. Palpa lies close to the junction of the valleys of Rio Grande, Rio Palpa, and Rio Viscas. The area is highly attractive for archaeological investigations on the Paracas and Nasca period as there is a vast number of geoglyphs in the immediate vicinity of settlements of the various time intervals. The context of the more than $100{ }^{14} \mathrm{C}$ samples used to build the numerical chronology is described in detail elsewhere (Unkel 2006) and in the excavation reports of Reindel, Isla Cuadrado, and colleagues (cited by Unkel [2006]).

\section{METHODS}

Samples have been pretreated using standard laboratory procedures (Unkel 2006). The AMS targets were prepared in Heidelberg using the newly built semi-automated graphitization system (Unkel 2006), and were measured in the Zurich AMS facility. In addition to commonly used sample material (Table 3 in Appendix), we collected adobe (clay bricks). Adobe is a common building material throughout Peru, used by the pre-Columbian cultures for domestic and also for ceremonial buildings, such as Cahuachi near the city of Nasca. As the adobe bricks typically contain single-year plant material, they offer almost immediate access to the time of erecting the buildings from which the samples were taken. So far, this material has rarely been used in Peru for dating pre-Hispanic adobe architecture. By selective sieving (1-mm mesh size), we recovered organic fragments from the adobe, such as maize straw and charcoal pieces (Unkel 2006).

For ${ }^{14} \mathrm{C}$ age calibration, we used OxCal v 3.8 (Bronk Ramsey 1995, 2001). Although already applied in several fields of archaeology, Bayesian statistics have only rarely been used in the investigation of the pre-Columbian cultures of south Peru (Görsdorf and Reindel 2002; Michczyński et al. 2003). However, for building a coherent ${ }^{14} \mathrm{C}$ chronology this statistical approach is mandatory (Buck and Millard 2004).

The fundamental idea of Bayesian theory is that it is possible to quantify the probability of certain assumptions, events, or data sets under the condition of some prior or a priori information (Bayes 1763). This information can simply be the stratigraphic position of 2 single samples or can be extended to the affiliation of a group of samples to a certain phase. In the case of the Paracas-Nasca chronology, this would be the attribution of each sample to a certain ceramic phase (Figure 2), based on the excavational context and the association of organic sample material with ceramic finds. 


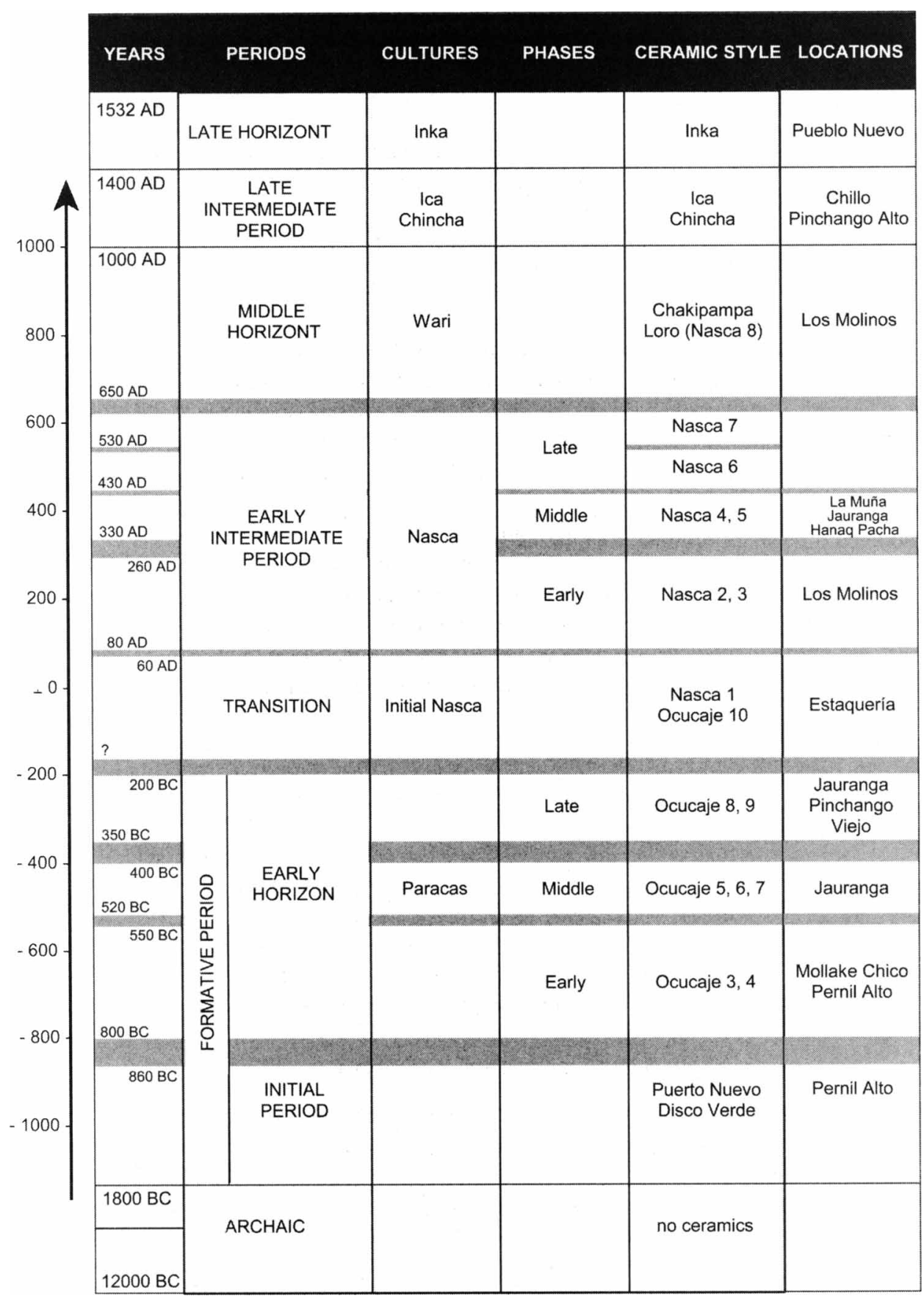

Figure 2 Chronology of the Paracas and Nasca cultures at the southern coast of Peru, based on our work on more than $100{ }^{14} \mathrm{C}$ dates of samples from ceramics-bearing excavation contexts in the Palpa area. Gray areas mark transitional zones between the single phases, caused by the overlap of the $1-\sigma$ probability intervals of each calculated phase. The pre-Paracas and post-Nasca periods are neither dated nor discussed here and are shown only for context purposes. 
A first approach to build a Nasca chronology based on this Bayesian statistical approach was performed by Görsdorf and Reindel (2002) with 12 samples from well-documented excavations in Los Molinos and La Muña. They calibrated the ${ }^{14} \mathrm{C}$ ages with OxCal v 3.5 (Bronk Ramsey 1995, 2001) using the IntCal98 calibration curve (Stuiver et al. 1998).

In 2 aspects of the calibration, we slightly differ from the previous approach of Görsdorf and Reindel (2002):

- They applied a Southern Hemisphere correction of $-24 \pm 3{ }^{14} \mathrm{C}$ yr based on Stuiver et al. (1998), while we used a correction of $-41 \pm 14{ }^{14} \mathrm{C}$ yr after McCormac et al. (2002). We decided not to apply a larger correction of $-55 \pm 7.9{ }^{14} \mathrm{C}$ yr as suggested by the new calibration curve for the Southern Hemisphere, SHCal04 (McCormac et al. 2004), because McCormac et al. define the Southern Hemisphere as south of the thermal equator or south of the range of the Intertropical Convergence Zone (ITCZ). Our research area is located at $14^{\circ} 30^{\prime} \mathrm{S}$, and we therefore assume to have a lower offset towards the Northern Hemisphere.

- Görsdorf and Reindel (2002) do not use statistical boundaries for their chronology model, neither for defining single phases nor for separating 2 phases that can be distinguished archaeologically. However, using boundaries is strongly recommended by Bronk Ramsey (2001), as modeled time spans without boundaries tend to spread disproportionately.

Both in Görsdorf and Reindel (2002) and here, the sum function of the OxCal syntax (Bronk Ramsey 2001) is employed for adding probability distributions of single samples to arrive at the best estimate for the chronological distribution of each Paracas and Nasca phase to be determined. It is important to note that the $1-\sigma$ range for a sum distribution gives an estimate for the period in which $68.2 \%$ of the events took place and not the period in which one can be sure with $68.2 \%$ probability that all of the events took place (Bronk Ramsey 2001). Due to this difference, it is possible that single samples, which were previously included in the statistical model of a Paracas or Nasca phase, ultimately end up outside the calculated phase after running the model (for further considerations on outliers see Buck and Millard [2004]).

\section{DISCUSSION}

The results of the modeled Paracas-Nasca chronology are summarized in Figure 2. Information on the samples used for the chronology is given in Table 3 (Appendix). The output of the OxCal model showing the probability distributions of the samples and the calculated phases can be found in Figure 3 (Appendix).

For the Initial period, preceding the Paracas phase, there were $11{ }^{14} \mathrm{C}$ samples from Pernil Alto (Figure 1) available to be included into the chronology model. Due to the archaeological context, they are all ascribed to the final phase of the Initial period. The end of this epoch is well defined by 7 dates for the last period of use of the site. We do not have information about the beginning and the duration of the Initial period (for details see Unkel [2006]). In fact, the sample of the Initial period can be perfectly used as the lower boundary of the Paracas chronology. The Early Paracas phase is represented by only 3 samples from the location of Mollake Chico near Palpa. We therefore have a first estimate of the time range of this phase; however, more samples, especially from the transition between the Initial period and Early Paracas, are necessary to narrow the error margins. Eleven samples are available from the Middle Paracas and 24 samples are available from the Late Paracas phase, providing a strong backbone for this time span. Up to now, all of these ${ }^{14} \mathrm{C}$ samples were excavated in Jauranga (Figure 1), yet a comparison with samples of the same period from Pernil Alto is expected soon. The Initial Nasca phase is represented by 6 samples, all derived from a single 
archaeological complex at Estaquería (Figure 1). Based on these few samples, the transition between the Paracas and Initial Nasca could not yet be modeled sufficiently (Figure 2). There still is an imprecise time gap between $200 \mathrm{cal}$ BC (upper 1- $\sigma$ boundary of the Late Paracas phase) and 50 cal BC (lower $1-\sigma$ boundary of the Initial Nasca phase), which has to be closed by ${ }^{14} \mathrm{C}$ samples from future excavations. The 5 samples from Los Molinos (Figure 1), which Görsdorf and Reindel (2002) used for a first approach to the Early Nasca phase, were also included in our Paracas-Nasca chronology model. The transition between the Initial Nasca and Early Nasca phase could be determined quite well, between cal AD 60 and 80 within the 1- $\sigma$ uncertainty margins. The Middle Nasca phase is very well dated, based on $17{ }^{14} \mathrm{C}$ samples from different excavational contexts defining a time span between cal AD 260 and $430(1 \sigma)$. Seven ${ }^{14} \mathrm{C}$ samples were used to determine the Late Nasca phase. Based on the style of the associated pottery in the archaeological context, all samples were ascribed to the Nasca 7 ceramic phase (compare Table 2). There were no ${ }^{14} \mathrm{C}$ samples available from the Nasca 6 phase. With the upper 1- $\sigma$ boundary of the Middle Nasca phase at cal AD 430 and the lower 1- $\sigma$ boundary of the Nasca 7 phase at cal AD 530, the Nasca 6 phase can be defined as a time gap of about $100 \mathrm{yr}$ based on our data. However, further archaeological investigations on the Nasca pottery have to show if this phase definition is justified. The end of the Nasca time in our chronology is only defined by the upper $1-\sigma$ boundary of the Nasca 7 phase at cal AD 650 .

\section{CONCLUSIONS}

More than $100{ }^{14} \mathrm{C}$ samples provide for the first time a stable numerical framework for the ceramicderived periods of the pre-Columbian Paracas and Nasca cultures at the south Peruvian coast. The chronology model can easily integrate new ${ }^{14} \mathrm{C}$ data from our ongoing work, and it can be adapted to new archaeological findings due to its open structure based on the Bayesian approach of OxCal. The relative ceramic chronology of the Paracas (Wetter 2005) and Nasca (Reindel et al. 1999) cultures was confirmed by our numerical data. Furthermore, adobe (clay bricks) has been successfully dated with the AMS technique and was integrated into the chronology presented above.

\section{ACKNOWLEDGMENTS}

The fieldwork was undertaken under permission of the Instituto Nacional de Cultura (INC), Lima. The German Embassy, Lima, supplied us with logistic support. The project was funded by the German Federal Ministry of Education and Research (BMBF) through their priority program NTG (Neue naturwissenschaftliche Methoden und Technologien in den Geisteswissenschaften) - project number 03WAX3VP. The archaeological research was also supervised by Johny Isla (INDEA, Lima). The AMS ${ }^{14} \mathrm{C}$ measurements were performed at the PSI/ETH Zurich, with support from Irka Hajdas, Georges Bonani, and Martin Suter. To all these colleagues and institutions, we would like to express our sincere thanks. We also thank Bertil Mächtle for compiling the map of Figure 1 and the 2 anonymous reviewers for their kind and helpful comments.

\section{REFERENCES}

Bayes TR. 1763. An essay towards solving a problem in the doctrine of chances. Philosophical Transactions (1683-1775) 53:370-418.

Bronk Ramsey C. 1995. Radiocarbon and analysis of stratigraphy: the OxCal program. Radiocarbon 37(2): 425-30.

Bronk Ramsey C. 2001. Development of the radiocarbon calibration program. Radiocarbon 43(2A):355-63.

Buck CE, Millard AR, editors. 2004. Tools for Constructing Chronologies: Crossing Disciplinary Boundaries.
London: Springer-Verlag. 257 p.

Burger RL. 1981. The radiocarbon evidence for the temporal priority of Chavin de Huantar. American Antiquity 46(3):592-602.

DeLeonardis L. 1997. Paracas settlement in Callango, lower Ica Valley, 1st millenium B.C., Peru [PhD dissertation]. Washington D.C.: Catholic University of America.

Disselhoff HD. 1969. Früh-Nazca im äußersten Süden Peru, Provincia de Camaná (Dep. Arequipa). In: Ver- 
handlungen des 38. Internationalen Amerikanisten Kongresses Stuttgart-München 1968. p 385-91. In German.

Eggert MKH. 2001. Prähistorische Archäologie: Konzepte und Methoden. Tübingen, Basel: Francke. 412 p. In German.

Gayton AH, Kroeber AL. 1927. The Uhle pottery collections from Nazca. University of California Publications in American Archaeology and Ethnology 24(1): $1-46$.

Görsdorf J, Reindel M. 2002. Radiocarbon dating of the Nasca settlements Los Molinos and La Muña in Palpa, Peru. Geochronometria 21:151-6.

Hecht N. 2007. Eine befundorientierte relative Chronologie der Nasca-Keramik in Palpa [PhD dissertation]. Bonn: Rheinische Friedrich-Wilhelms Universität. In German.

Joyce TA. 1912. South American Archaeology. New York: G.P. Putnam's Sons. 292 p.

Lambers K. 2004. The geoglyphs of Palpa (Peru): documentation, analysis, and interpretation [PhD dissertation]. Zurich: University of Zurich. Abstract available online at http://www.dissertationen.unizh.ch/2005/ lambers/abstract.html.

McCormac FG, Reimer PJ, Hogg AG, Higham TFG, Baillie MGL, Palmer J, Stuiver M. 2002. Calibration of the radiocarbon time scale for the Southern Hemisphere: AD 1850-950. Radiocarbon 44(3):641-51.

McCormac FG, Hogg AG, Blackwell PG, Buck CE, Higham TFG, Reimer PJ. 2004. SHCal04 Southern Hemisphere calibration, 0-11.0 cal kyr BP. Radiocarbon 46(3):1087-92.

Menzel D. 1971. Estudios arqueológicos en los Valles de Ica, Pisco, Chincha y Cañete. Arqueología y Sociedad 6:1-158. In Spanish.

Menzel D, Rowe JH, Dawson LE. 1964. The Paracas Pottery of Ica: A Study in Style and Time. Berkeley: University of California Press. 399 p.

Michczyński A, Eeckhout P, Pazdur A. 2003. ${ }^{14} \mathrm{C}$ absolute chronology of Pyramid III and the dynastic model at Pachacamac, Peru. Radiocarbon 45(1):59-73.

Paul A, editor. 1991. Paracas Art and Architecture: $O b$ ject and Context in South Coastal Peru. Iowa City: University of Iowa Press. $455 \mathrm{p}$.

Reindel M, Isla Cuadrado J, Koschmieder K. 1999. Vorspanische Siedlungen und Bodenzeichnungen in Palpa, Südperu. Beiträge zur Allgemeinen und Vergleichenden Archäologie (BAVA) 19:313-81. In German and Spanish.

Reindel M, Isla Cuadrado J. 2001. Los Molinos und La Muña. Zwei Siedlungszentren der Nasca-Kultur in Palpa, Südperu. Beiträge zur Allgemeinen und Vergleichenden Archäologie (BAVA) 21:241-319. In German and Spanish.

Reindel M, Isla Cuadrado J, Lambers K. 2003. Die Arbeiten des Archäologischen Projektes Nasca-Palpa, Peru, im Jahr 2002. In: Jahresbericht der Schweiz-
erisch-Liechtensteinischen Stiftung für Archäologische Forschungen im Ausland (2002). Zurich and Vaduz. p 119-32. In German.

Rowe JH. 1959. Archaeological dating and cultural process. Southwestern Journal of Anthropology 15(4): 317-24.

Rowe JH. 1960. Nuevos datos relativos a la cronología del Estilo Nasca. In: Matos RM, editor. Antiguo Perú: Espacio y Tiempo. Lima: Juan Mejia Baca. p 29-45. In Spanish.

Rowe JH. 1967. An interpretation of radiocarbon measurements on archaeological samples from Peru. In: Rowe JH, Menzel D, editors. Peruvian Archaeology: Selected Readings. Palo Alto, California, USA: Peek Publications. p 16-30.

Silverman H. 1991. The Paracas problem: archaeological perspectives. In: Paul A, editor. Paracas Arts and Architecture. Object and Context in South Coastal Peru. Iowa City: University of Iowa Press. p 349-414.

Silverman H, Proulx DA. 2002. The Nasca. Kolata A, Snow D, series editors. Peoples of America series. Oxford: Blackwell. $360 \mathrm{p}$.

Stuiver M, Reimer PJ, Bard E, Beck JW, Burr GS, Hughen KA, Kromer B, McCormac G, van der Plicht J, Spurk M. 1998. IntCal98 radiocarbon age calibration, 24,000-0 cal BP. Radiocarbon 40(3): 1041-83.

Tello JC. 1917. Los antiguos cementerios del valle de Nazca. In: Swiggett D, editor. Proceedings of the Second Pan American Scientific Congress, Washington, USA. Volume 1. Washington D.C.: Government Printing Office. p 283-91. In Spanish.

Uhle M. 1914. The Nasca pottery of ancient Peru. Proceedings of the Davenport Academy of Sciences 13:117. Davenport, Iowa, USA.

Unkel I. 2006. AMS-14C-Analysen zur Rekonstruktion der Landschafts- und Kulturgeschichte in der Region Palpa (S-Peru) [PhD dissertation]. Heidelberg: Universität Heidelberg. Available online at http:// www.ub.uni-heidelberg.de/archiv/6311. 156 p. In German.

Velarde L. 1997. La transición Paracas-Nasca en el valle de Chincha. In: Chevalier A, Velarde L, Chenal-Velarde I, editors. L'Amerique du Sud: Des chasseurscueilleurs à l'Empire Inca. Actes des journées d'étude d'archéologie précolombienne. British Archaeological Reports (BAR) International Series 746. Geneva, Switzerland, 10-11 October 1997. Oxford: Archaeopress. p 63-77. In Spanish.

Wetter A. 2005. Paracas-Keramik aus Jauranga: Grundlagen zur Klassifikation formativzeitlicher Keramik der Südküste Perus [Master's thesis]. Bonn: Rheinische Friedrich-Wilhelms-Universität, Bonn. In German.

Ziolkowski M, Pazdur M, Krzanowski A, Michczyński A. 1994. ANDES: Radiocarbon Database for Bolivia, Ecuador and Peru. Warsaw and Gliwice: Warsaw University \& Silesian Technical University. 


\section{APPENDIX}

Table 3 The ${ }^{14} \mathrm{C}$ samples used for the Paracas and Nasca chronology. Calibration is based on IntCal98 (Stuiver et al. 1998) using a Southern Hemisphere offset of $-41 \pm 14{ }^{14} \mathrm{C}$ yr.

\begin{tabular}{|c|c|c|c|c|c|c|c|c|c|c|}
\hline $\mathrm{Nr}$ & $\begin{array}{l}\text { Invent. } \\
\mathrm{nr}\end{array}$ & $\begin{array}{l}\text { Analysis } \\
\mathrm{nr}\end{array}$ & Type & $\begin{array}{l}\text { Sample } \\
\text { size }(\mathrm{mg})\end{array}$ & $\begin{array}{l}\delta^{13} \mathrm{C} \\
(\% o)\end{array}$ & $\begin{array}{l}{ }^{14} \mathrm{C} \text { age } \\
\text { (BP) }\end{array}$ & $\begin{array}{l}\text { St. dv. } \\
\text { (BP) }\end{array}$ & $\begin{array}{l}1-\sigma \text { age range } \\
\text { (cal AD/BC) }\end{array}$ & Site & $\begin{array}{l}\text { Sample } \\
\text { material }\end{array}$ \\
\hline 1 & 27 & ET369 & AMS & 91.105 & -20.00 & 1675 & 49 & $340-540 \mathrm{AD}$ & PAP-93 & bone \\
\hline 2 & 55 & HD-23212 & GP & 13,800 & -23.62 & 1737 & 20 & $260-400 \mathrm{AD}$ & PAP-79 & vood \\
\hline 3 & " & HD-23213 & GP & 7000 & -24.64 & 1697 & 22 & $355-430 \mathrm{AD}$ & PAP-79 & wood \\
\hline 4 & " & ET154 & AMS & 3.31 & -24.60 & 1620 & 49 & 420-540 AD & PAP-79 & wood \\
\hline 5 & " & ET166 & AMS & 5.21 & -23.30 & 1825 & 54 & $130-340 \mathrm{AD}$ & PAP-79 & wood \\
\hline 6 & 83 & HD-23091 & GP & 2790 & -24.27 & 554 & 35 & $1404-1437 \mathrm{AD}$ & PAP-61 & charcoal \\
\hline 7 & $"$ & ET122 & AMS & 5.6 & -20.90 & 365 & 35 & $1510-1640 \mathrm{AD}$ & " & " \\
\hline 8 & 84 & HD-23123 & GP & 5430 & -27.71 & 3470 & 21 & $1750-1685$ BC & PAP-61 & charcoal \\
\hline 9 & 90 & HD-23977 & GP & 8600 & -26.91 & 1512 & 14 & $560-640 \mathrm{AD}$ & PAP-64B & wood \\
\hline 10 & $"$ & ET443 & AMS & 3.86 & -28.60 & 1460 & 45 & $595-665 \mathrm{AD}$ & $"$ & $"$ \\
\hline 11 & 109 & HD-23978 & GP & 10,000 & -25.21 & 1611 & 13 & 435-535 AD & PAP-64A & wood \\
\hline 12 & 112 & HD- 23 & GP & 9580 & -27.44 & 1484 & 18 & $A D$ & & wood \\
\hline 13 & 116 & HD-23981 & GP & 10,000 & -26.74 & 1562 & 12 & $535-600 \mathrm{AD}$ & PAP- & wood \\
\hline 14 & 118 & HD-23914 & GP & 10,500 & -26.89 & 2835 & 19 & $\mathrm{BC}$ & $\mathrm{PAI}$ & wood \\
\hline 15 & 123 & HD-2 & GP & 9900 & -25.52 & 1748 & 17 & $A D$ & & wo \\
\hline 16 & $"$ & HD-2 & GP & 10,400 & -26.46 & 1744 & 16 & $A D$ & & wo \\
\hline 17 & " & ET12 & AMS & 5.7 & -27.20 & 1620 & 40 & AD & " & " \\
\hline 18 & $"$ & ET16 & AMS & 4.33 & -24.40 & 1745 & 54 & $A D$ & $"$ & $"$ \\
\hline 19 & 131 & 3782 & GP & 6400 & -26.37 & 1499 & 23 & $A D$ & PAF & wood \\
\hline 20 & 133 & 851 & GP & 6700 & -23.76 & 1705 & 28 & & & wo \\
\hline 21 & $"$ & ET114 & AMS & 3.0 & -25.70 & 1735 & 45 & 260 & $"$ & $"$ \\
\hline 22 & 134 & HD-23785 & GP & 2470 & -27.41 & 1664 & 118 & $\mathrm{AD}$ & PAP-365 & wood \\
\hline 23 & 136 & 783 & GP & 4390 & -25.00 & 1747 & 36 & $\mathrm{AD}$ & & wood \\
\hline 24 & 139 & HD-23074 & GP & 4910 & -26.68 & 1635 & 20 & $\mathrm{AD}$ & PAP-379B & wood \\
\hline 25 & $"$ & ET121 & AMS & 6.2 & -27.80 & 1575 & 40 & $\mathrm{AD}$ & " & $"$ \\
\hline 26 & 178 & $\Gamma 156$ & AMS & 3.93 & -22.40 & 2215 & 49 & $360-120 \mathrm{BC}$ & PAF & charco \\
\hline 27 & 179 & ET158 & AMS & 4.235 & -30.80 & 2315 & 54 & $400-2$ & $\mathrm{PAI}$ & charcoal \\
\hline 28 & 180 & HD-23632 & GP & 5100 & -23.02 & 149 & 23 & $\begin{array}{l}1690-1730 \mathrm{AD} \\
1810-1890 \mathrm{AD} \\
1910-1920 \mathrm{AD}\end{array}$ & PAP-79 & branches \\
\hline 29 & 181 & ET185 & AMS & 27.285 & -28.90 & 190 & 45 & $\begin{array}{l}1670-1950 \mathrm{AD} \\
1720-1780 \mathrm{AD}\end{array}$ & PAP-79 & soil \\
\hline 30 & 182 & & AMS & 11. & -22.10 & 350 & 54 & $\mathrm{AD}$ & & soil \\
\hline 31 & 183 & & AMS & 5.11 & -11.40 & 500 & 49 & $1410-1480 \mathrm{AD}$ & & charcoal \\
\hline 32 & 184 & ET131 & AMS & 3.7 & -20.30 & 430 & 50 & $\begin{array}{l}1440-1530 \mathrm{AD} \\
1590-1630 \mathrm{AD}\end{array}$ & PAP-79 & charcoal \\
\hline 33 & 185 & ET180 & AMS & 6.625 & -28.9 & 400 & 45 & $\begin{array}{l}1470-1530 \mathrm{AD} \\
1560-1640 \mathrm{AD}\end{array}$ & PAP-79 & soil \\
\hline 34 & 186 & ET153 & AMS & 4.71 & -27.2 & 400 & 45 & $\begin{array}{l}1470-1530 \mathrm{AD} \\
1560-1640 \mathrm{AD}\end{array}$ & PAP-79 & soil \\
\hline 35 & 187 & ET179 & AMS & 6.77 & -24.2 & 580 & 54 & $\begin{array}{l}1320-1350 \mathrm{AD} \\
1390-1440 \mathrm{AD}\end{array}$ & PAP-79 & soil \\
\hline 36 & 189 & ET174 & AMS & 7.55 & -29.7 & 190 & 49 & $\begin{array}{l}1670-1880 \mathrm{AD} \\
1910-1950 \mathrm{AD}\end{array}$ & PAP-79 & wood \\
\hline 37 & 190 & ET181 & AMS & 19.69 & -23.6 & 380 & 45 & $\begin{array}{l}1480-1530 \mathrm{AD} \\
1540-1640 \mathrm{AD}\end{array}$ & PAP-79 & soil \\
\hline
\end{tabular}


Table 3 The ${ }^{14} \mathrm{C}$ samples used for the Paracas and Nasca chronology. Calibration is based on IntCal98 (Stuiver et al. 1998) using a Southern Hemisphere offset of $-41 \pm 14{ }^{14} \mathrm{C}$ yr. (Continued)

\begin{tabular}{|c|c|c|c|c|c|c|c|c|c|c|}
\hline $\mathrm{Nr}$ & $\begin{array}{l}\text { Invent. } \\
\mathrm{nr}\end{array}$ & $\begin{array}{l}\text { Analysis } \\
\mathrm{nr}\end{array}$ & Type & $\begin{array}{l}\text { Sample } \\
\text { size }(\mathrm{mg})\end{array}$ & $\begin{array}{l}\delta^{13} \mathrm{C} \\
(\% o)\end{array}$ & $\begin{array}{l}{ }^{14} \mathrm{C} \text { age } \\
\text { (BP) }\end{array}$ & $\begin{array}{l}\text { St. dv. } \\
\text { (BP) }\end{array}$ & $\begin{array}{l}1-\sigma \text { age range } \\
\text { (cal AD/BC) }\end{array}$ & Site & $\begin{array}{l}\text { Sample } \\
\text { material }\end{array}$ \\
\hline 38 & 191 & ET177 & AMS & 3.315 & -23.9 & 575 & 49 & & PAP-79 & charcoal \\
\hline 39 & 193 & ET178 & AMS & 5.115 & -23.8 & 410 & 54 & $\begin{array}{l}1450-1530 \mathrm{AD} \\
1560-1630 \mathrm{AD}\end{array}$ & PAP-79 & charcoal \\
\hline 40 & 194 & ETH-30222 & AMS & 5.3 & -20.7 & 1990 & 60 & $40 \mathrm{BC}-130 \mathrm{AD}$ & PAP-79 & adobe \\
\hline 41 & $196 b$ & ETH-30220 & AMS & 6.0 & -20.4 & 2250 & 75 & $380-180 \mathrm{BC}$ & PAP-79 & \\
\hline 42 & $196 a$ & ETH-30221 & AMS & 5.2 & -22.2 & 1845 & 55 & $130-320 \mathrm{AD}$ & PAP-79 & $\begin{array}{l}\text { adobe, } \\
\text { straw }\end{array}$ \\
\hline 43 & 197 & ET189 & AMS & 6.37 & -23.4 & 1915 & 54 & $70-220 \mathrm{AD}$ & PAP-79-1 & \\
\hline 44 & 202 & ET112 & AMS & 4.3 & -18.80 & 1980 & 95 & & & \\
\hline 45 & 205 & HD-23089 & GP & 1780 & -18.57 & 669 & & & & \\
\hline 46 & $"$ & ET115 & AMS & 6.8 & -34.60 & 630 & 40 & & & $"$ \\
\hline 47 & 207 & HD-23087 & GP & 3130 & -16.76 & 635 & 24 & $1305-1405$ AD & PAP-396 & \\
\hline 48 & " & ET118 & AMS & 5. & -9.40 & 515 & 35 & & " & $"$ \\
\hline 49 & 215 & $\mathrm{E}$ & AMS & & -13.30 & 60 & & & & \\
\hline 50 & 219 & $\mathrm{H}$ & GP & 3320 & -19.21 & 82 & & & & \\
\hline 51 & $"$ & ET1 & AMS & 6.8 & -17.00 & 805 & 4 & & $"$ & \\
\hline 52 & 220 & & GP & 2690 & -23.24 & 904 & & & $"$ & $"$ \\
\hline 53 & 222 & ET16 & AMS & & -25.00 & 1940 & 5 & & & \\
\hline 54 & 224 & T164 & AMS & & -13.70 & 2460 & 68 & & & \\
\hline 55 & 227 & ET161 & AMS & 13.645 & -25.00 & 1970 & 54 & & PAP-93 & \\
\hline 57 & 246 & & AMS & & -5.40 & 1345 & 49 & & & \\
\hline 58 & 247 & E & AMS & & -25.30 & 1655 & & & & \\
\hline 59 & $"$ & ET17 & AMS & 8.0 & -25.90 & 1615 & 4 & & & \\
\hline 60 & 249 & HD- & GP & 2400 & -9.16 & 1462 & 26 & & & \\
\hline 61 & 25 & E & AMS & & -14.90 & 2910 & 70 & & & \\
\hline 62 & $"$ & & MS & 13.7 & -14.70 & 2600 & 54 & & & tile \\
\hline 63 & 251 & ET128 & AMS & 3.9 & -34.50 & 2495 & 45 & $760-410 \mathrm{BC}$ & Mollake & \\
\hline 64 & 289 & & GP & 10,280 & -24.84 & 2284 & & & & \\
\hline 65 & $"$ & ET43 & AMS & & -28.2 & 2325 & & & & \\
\hline 66 & 290 & & AMS & & 5.6 & 216 & 4 & & & \\
\hline 67 & 25 & & $\mathrm{AN}$ & & -27.0 & 21 & 4 & & & \\
\hline 68 & 292 & & AMS & & -26.3 & 2335 & & & & \\
\hline 69 & 293 & & GP & & -26.09 & 2324 & 2 & & & char \\
\hline 70 & 294 & HD-24234 & GP & 28,900 & -25.22 & 2283 & 22 & & & \\
\hline 71 & 296 & ET379 & AMS & 4.73 & -24.0 & 2450 & 45 & & & \\
\hline 72 & 297 & HD-24264 & GP & 12,000 & -22.55 & 2458 & 31 & & - 150 & charcoal \\
\hline 73 & 309 & ET381 & AMS & 4.62 & -24.5 & 2290 & 45 & & P-150 & charcoal \\
\hline 74 & 311 & & AMS & 10.28 & -22.8 & 2305 & 45 & & & \\
\hline 75 & 312 & ET431 & AMS & 3.71 & -25.1 & 2375 & 49 & & -150 & \\
\hline 76 & 314 & HD- 24263 & GP & 8600 & -24.19 & 2247 & 23 & & & charcoal \\
\hline 77 & 315 & ET432 & AMS & 3.79 & -24.7 & 2325 & 49 & & & soil \\
\hline 78 & 316 & ET433 & AMS & 4.75 & -28.7 & 2230 & 49 & $360-270 \mathrm{BC}$ & PAP-150 & soil \\
\hline
\end{tabular}


Table 3 The ${ }^{14} \mathrm{C}$ samples used for the Paracas and Nasca chronology. Calibration is based on IntCal98 (Stuiver et al. 1998) using a Southern Hemisphere offset of $-41 \pm 14{ }^{14} \mathrm{C}$ yr. (Continued)

\begin{tabular}{|c|c|c|c|c|c|c|c|c|c|c|}
\hline $\mathrm{Nr}$ & $\begin{array}{l}\text { Invent. } \\
\mathrm{nr}\end{array}$ & $\begin{array}{l}\text { Analysis } \\
\mathrm{nr}\end{array}$ & Type & $\begin{array}{l}\text { Sample } \\
\text { size }(\mathrm{mg})\end{array}$ & $\begin{array}{l}\delta^{13} \mathrm{C} \\
(\% o)\end{array}$ & $\begin{array}{l}{ }^{14} \mathrm{C} \text { age } \\
\text { (BP) }\end{array}$ & $\begin{array}{l}\text { St. dv. } \\
\text { (BP) }\end{array}$ & $\begin{array}{l}1-\sigma \text { age range } \\
\text { (cal } \mathrm{AD} / \mathrm{BC} \text { ) }\end{array}$ & Site & $\begin{array}{l}\text { Sample } \\
\text { material }\end{array}$ \\
\hline 79 & 317 & ET446 & AMS & 5.70 & -31.9 & 2290 & 54 & $390-200 \mathrm{BC}$ & PAP-150 & charcoal \\
\hline 80 & 318 & ET447 & AMS & 4.69 & -30.6 & 2285 & 54 & $390-200 \mathrm{BC}$ & PAP-150 & charcoal \\
\hline 81 & 319 & ET448 & AMS & 4.25 & -26.7 & 2330 & 54 & $410-210 \mathrm{BC}$ & PAP- 150 & charcoal \\
\hline 82 & 320 & ET449 & AMS & 4.85 & -26.7 & 2190 & 54 & $360-90 \mathrm{BC}$ & PAP-150 & charcoal \\
\hline 83 & 321 & ET451 & AMS & 4.87 & -24.0 & 2300 & 54 & $400-200 \mathrm{BC}$ & PAP- 150 & charcoal \\
\hline 84 & 322 & ET452 & AMS & 4.10 & -21.1 & 2305 & 49 & $400-200 \mathrm{BC}$ & & charcoal \\
\hline 85 & 323 & ET453 & AMS & 3.25 & -25.9 & 2430 & 54 & $760-390 \mathrm{BC}$ & & charcoal \\
\hline 86 & 324 & ET458 & AMS & 4.78 & -21.6 & 2380 & 49 & $520-250 \mathrm{BC}$ & & harcoal \\
\hline 87 & 325 & ET454 & AMS & 3.70 & -24.1 & 2420 & 54 & $760-390 \mathrm{BC}$ & AP- 150 & harcoal \\
\hline 88 & 326 & ET456 & AMS & 3.25 & -26.2 & 2270 & 54 & $00 \mathrm{BC}$ & 150 & soil \\
\hline 89 & 327 & ET457 & AMS & 4.65 & -21.1 & 2485 & 54 & $00 \mathrm{BC}$ & 150 & charcoal \\
\hline 90 & 335 & ET462 & AMS & 5.59 & -24.4 & 2255 & 49 & $00 \mathrm{BC}$ & 150 & charcoal \\
\hline 91 & 336 & ET463 & MS & 4.57 & -26.8 & 2220 & 54 & $60 \mathrm{BC}$ & 150 & charcoal \\
\hline 92 & 338 & 466 & MS & 5.72 & -22.6 & 2460 & 54 & $00 \mathrm{BC}$ & 150 & soil \\
\hline 93 & 339 & $\Gamma 459$ & MS & 14.25 & -26.4 & 2335 & 54 & $10 \mathrm{BC}$ & 150 & soil \\
\hline 94 & 340 & ET461 & AMS & 4.48 & -23.3 & 2505 & 54 & $10 \mathrm{BC}$ & 150 & soil \\
\hline 95 & 341 & ET467 & AMS & 21.02 & -22.3 & 2330 & 54 & $10 \mathrm{BC}$ & -150 & soil \\
\hline 96 & 342 & ET602 & AMS & 9.61 & -22.2 & 2415 & 54 & $80 \mathrm{BC}$ & -150 & soil \\
\hline 97 & 343 & ET603 & AMS & 5.87 & -27.1 & 2415 & 49 & $80 \mathrm{BC}$ & -150 & charcoal \\
\hline 98 & 344 & ET604 & AMS & 6.36 & -25.5 & 2430 & 54 & $90 \mathrm{BC}$ & -150 & charcoal \\
\hline 99 & 372 & HD-24208 & GP & 10,420 & -25.44 & 2878 & 19 & $25 \mathrm{BC}$ & -266 & wood \\
\hline 100 & 373 & HD-24265 & GP & 10,000 & -26.52 & 2840 & 24 & $1000-900 \mathrm{BC}$ & -266 & wood \\
\hline 101 & 374 & ET361 & AMS & 3.75 & -26.40 & 2830 & 45 & $1000-840 \mathrm{BC}$ & PAP-266 & wood \\
\hline 102 & 375 & ET386 & AMS & 6.74 & -25.60 & 2840 & 49 & $1010-840 \mathrm{BC}$ & PAP-266 & wood \\
\hline 103 & 376 & ET362 & AMS & 5.50 & -28.50 & 2810 & 49 & $980-830 \mathrm{BC}$ & PAP-266 & wood \\
\hline 104 & 377 & ET363 & AMS & 5.45 & -25.80 & 1685 & 45 & $260-530 \mathrm{AD}$ & PAP-266 & \\
\hline 105 & 378 & ET3 & AMS & 3.97 & -23.70 & 2885 & 45 & $1110-910 \mathrm{BC}$ & PAP-266 & \\
\hline 106 & 379 & ET358 & AMS & 3.52 & -31.10 & 2790 & 49 & $970-830 \mathrm{BC}$ & AP-266 & coal \\
\hline 107 & 380 & HD-2 & GP & 3010 & -26.00 & 2889 & 18 & $0 \mathrm{BC}$ & -266 & coal \\
\hline 108 & 381 & & AMS & 3.76 & -28.50 & 2860 & 49 & $\mathrm{BC}$ & & coal \\
\hline 109 & 382 & ET383 & AMS & 3.96 & -26.60 & 2925 & 49 & $1190-970$ BC & & $\begin{array}{l}\text { seed, } \\
\text { pumpkin }\end{array}$ \\
\hline 110 & 383 & HD-24071 & GP & 6400 & -26.08 & 2047 & 24 & $45 \mathrm{BC}-50 \mathrm{AD}$ & PAP-73D & wood \\
\hline 111 & $"$ & ET366 & AMS & 3.81 & -28.50 & 1970 & 45 & $20-130 \mathrm{AD}$ & PAP-73D & wood \\
\hline 112 & 384 & HD- 24072 & GP & 5840 & -26.30 & 1992 & 16 & $20-80 \mathrm{AD}$ & PAP-73D & wood \\
\hline 113 & 385 & HD-24073 & GP & 5160 & -25.88 & 2020 & 22 & $20 \mathrm{BC}-65 \mathrm{AD}$ & PAP-73D & wood \\
\hline 114 & 386 & HD-24066 & GP & 3080 & -27.60 & 2086 & 29 & $95 \mathrm{BC}-5 \mathrm{AD}$ & PAP-73D & wood \\
\hline 115 & 387 & ET364 & AMS & 3.825 & -29.20 & 2005 & 45 & $40 \mathrm{BC}-90 \mathrm{AD}$ & PAP-73D & charcoal \\
\hline
\end{tabular}




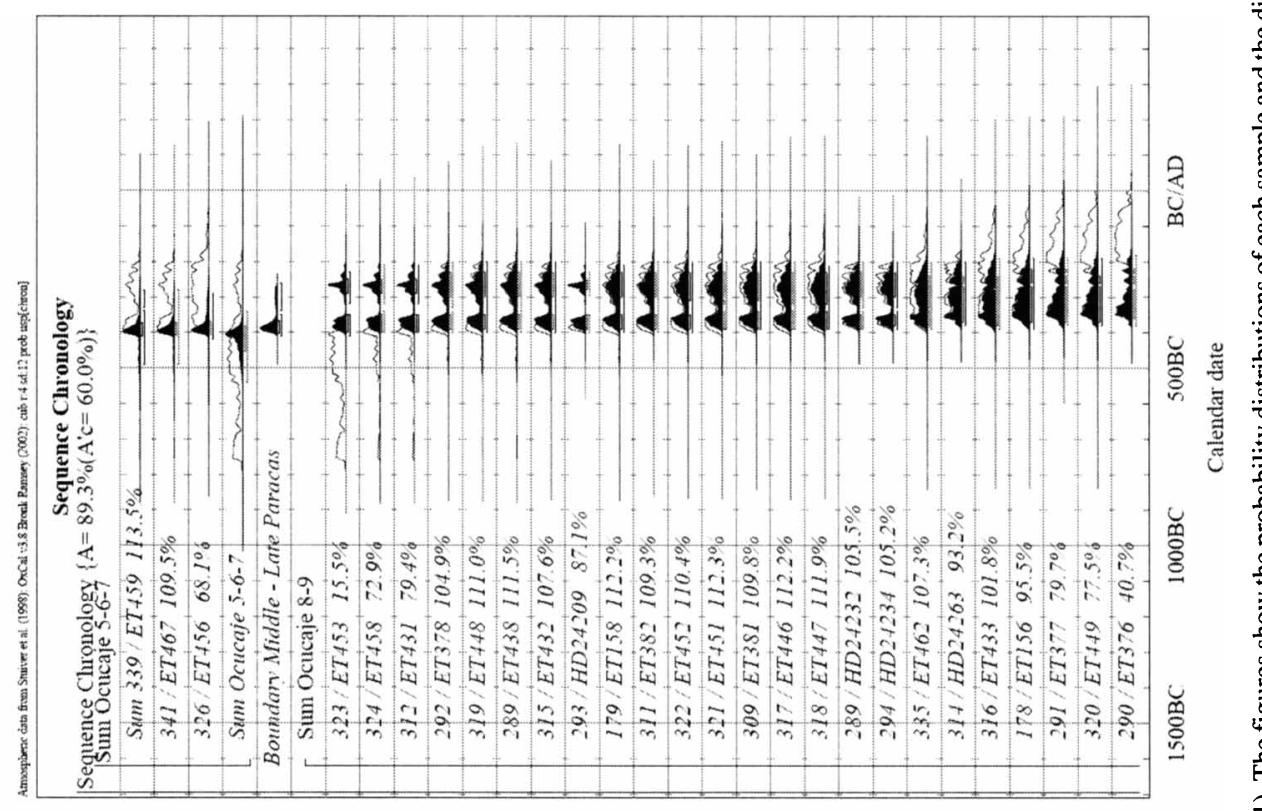

$\infty$

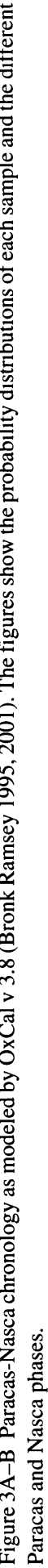




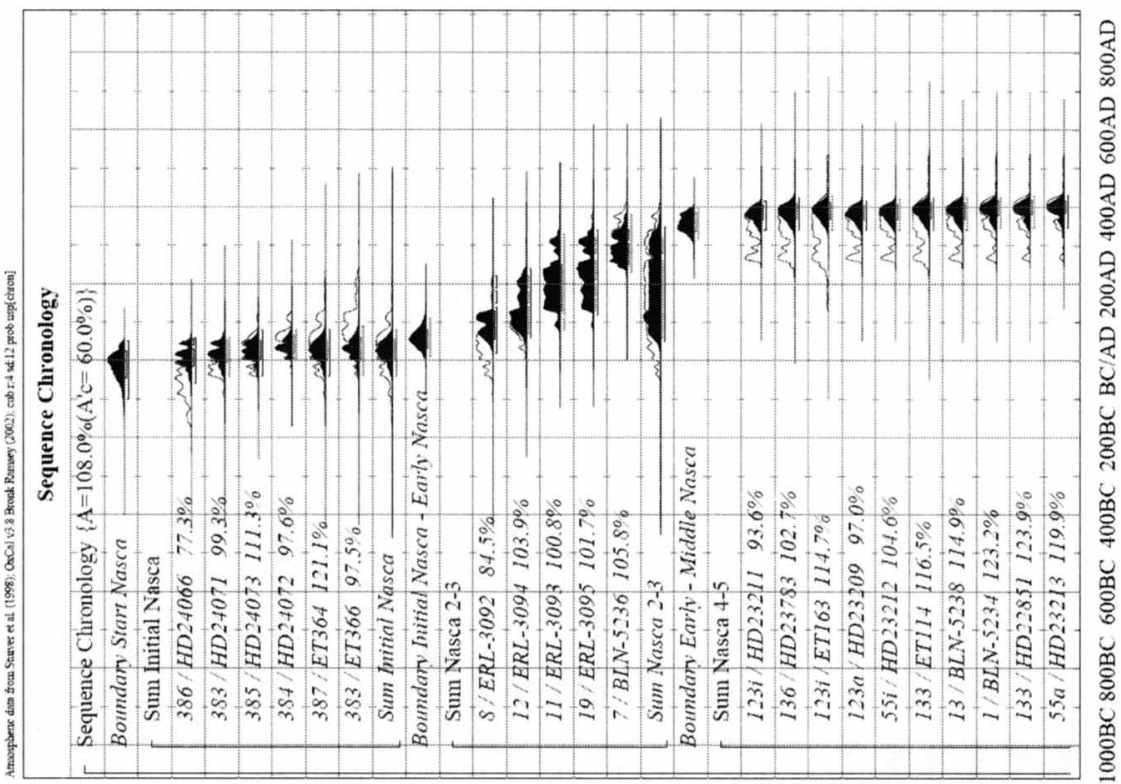

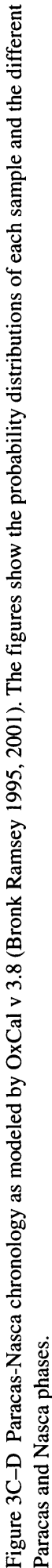




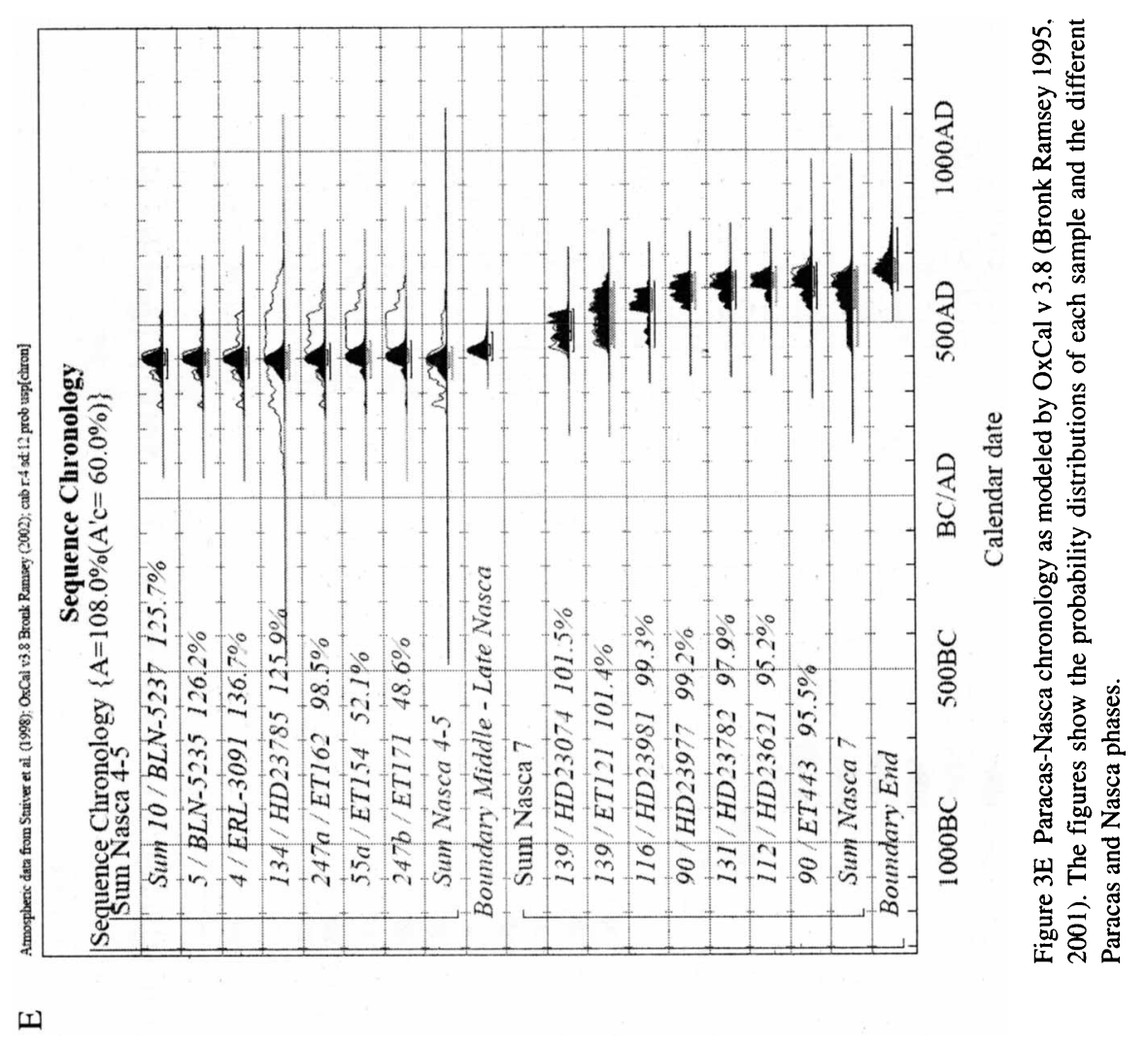

